\title{
A2M Gene
}

National Cancer Institute

\section{Source}

National Cancer Institute. A2M Gene. NCI Thesaurus. Code C105922.

This gene has activity as a protease inhibitor. 